\title{
Pamuklu Kumaşın Bazı Fiziksel ve Kimyasal Özellikleri Üzerine Enzimatik Muamele Etkisinin Araştırılması
}

\author{
Şeyda Eyüpoğlu ${ }^{1 *}$, Nigar Merdan ${ }^{2}$ \\ ${ }^{1}$ İstanbul Üniversitesi - Cerrahpaşa, Teknik Bilimler Meslek Yüksekokulu, Tekstil, Giyim, Ayakkabı ve Deri Bölümü, İstanbul, Türkiye (ORCID: 0000-0003-4522- \\ 2056) \\ ${ }^{2}$ İstanbul Ticaret Üniversitesi, Mimarlık ve Tasarım Fakültesi, Moda ve Tekstil Tasarımı Bölümü, İstanbul, Türkiye (ORCID: 0000-0001-7246-4849)
}

(İlk Geliş Tarihi 9 Ocak 2020 ve Kabul Tarihi 31 Mart 2020)

(DOI: 10.31590 /ejosat.672653)

ATIF/REFERENCE: Eyüpoğlu, Ş. \& Merdan, N. (2020). Pamuklu Kumaşın Bazı Fiziksel ve Kimyasal Özellikleri Üzerine Enzimatik Muamele Etkisinin Araştırılması. Avrupa Bilim ve Teknoloji Dergisi, (18), 885-894.

\section{$\ddot{O} z$}

Tekstil endüstrisinde, pamuklu kumaşların yüzeyindeki havları uzaklaştırmak için alazlama (yakma) işlemi yapılmaktadır. Son yıllarda pamuklu kumaşlara alazlama yerine enzimatik hav giderme işlemi uygulanmaktadır. Bu nedenle bu çalışmada enzimatik işlem uygulanmış pamuklu kumaşların özellikleri incelenmiştir. Enzimatik işlem numunelere boyamadan önce, boyama esnasında ve boyama işleminden sonra uygulanmıştır. Selülaz enzimi uygulanmış numunelere, enzimatik işlemden sonra klasik ve ultrasonik enerji yöntemi ile yıkamalar yapılmıştır. Ardından çalışmada kullanılan kumaşların beyazlık dereceleri, renk ölçümleri, yıkama, sürtünme, ter ve 1şık haslığı ve boncuklanma özellikleri incelenmiştir. Sonuçlara göre, enzimatik işlem uygulanması ile birlikte numunelerin özelliklerinde iyileşmeler görülmüştür. Yıkamalarda ultrasonik enerjinin kullanımı ile enerji tasarrufu sağlanmıştır.

Anahtar Kelimeler: Enzimatik işlem, beyazlık derecesi, kolorometrik ölçümler, haslık değeri, boncuklanma.

\section{Investigation of the Effect of Enzymatic Treatment on Some Physical and Chemical Properties of Cotton Fabric}

\begin{abstract}
In textile industry, in order to remove of cotton nap, the scorching treatment has been carried out. In recent years, enzymatic nap removel treatment has been used to cotton fabrics instead of the scorching treatment. For this reason, in this study, the properties of cotton samples treated with enzymatic process were investigated. Enzymatic treatment was applied to the samples before, during and after dyeing process. After the enzymatic tretament, the samples were washed with convantional method and ultrasonic energy. After whitness index, colour measurement, washing, rubbing, perspiration and light fastness, and pilling properties of samples were investigated. According to the results, it was observed that properties of samples develop with enzymatic treatment. Using of ultrasonic energy in washing causes to energy saving.
\end{abstract}

Keywords: Enzymatic treatment, whitness index, colourometric measurement, fastness, pilling.

\section{Giriş}

Son yıllarda tekstil terbiyesinde çevre dostu üretim yaklaşımlarının kullanılması önemli bir konu haline gelmiştir. Enzimlerin tekstil terbiyesinde kullanımı çevre dostu üretim yaklaşımlarının başında gelmektedir. Bu işlemlerde kullanılan enzimler bakteri türevinden elde edilen canlı organizmaların metabolik ürünlerinden oluşan biyokatalizatörlerdir (Stöhr, 2004). Amilaz; haşıl sökmede, katalaz; ağartmadan sonra hidrojen peroksitin uzaklaştırılmasında, lakkaz; kot kumaşlarda indigo boyarmaddenin uzaklaştırılmasında, peroksidaz; reaktif boyarmaddelerde kovalent bağlanmamış boyarmaddenin oksidasyonunda, lipaz; iplik

\footnotetext{
* İstanbul Üniversitesi - Cerrahpaşa, Teknik Bilimler Meslek Yüksekokulu, Tekstil, Giyim, Ayakkabı ve Deri Bölümü, İstanbul, Türkiye (ORCID: 0000-0003-4522-2056)
} 
eğirmede yağların varlığında haşıl sökme işleminde, pektinaz; ham pamuk veya ketenin biyo temizlenmesinde, selülaz; jeans ve kot giysilerin enzimatik taş yıkanmasında ve mekanik etki ile lif yüzeyinden serbest fibril uçlarının uzaklaştırılmasında kullanılmaktadır. Kumaş yüzeyinden çıkan lif uçları boncuklanma probleminin nedenidir. Terbiye işlemlerinden önce enzimatik işlemin uygulanması ile boncuklanma probleminin önlenmesi hedeflenmektedir. Selülazlar, Aspergillus niger, Trichoderma longibrachiatum, Fusarium solani, Trichoderma viride'dan elde edilmiş yüksek moleküllü kolloidal proteinlerdir. Endüstriyel selülazlar, selülaz, sellobiaz ve ilgili enzimlerin tamamen düzgün olmayan bileşiklerinin kompleksleridir. Enzim katalizliğinde enzim-substrat kompleksi oluşturulur (selülaz- seluloz kompleksi). Selülazlar selulozun 1,4 $\beta$-glukozit bağlarını koparabilme yeteneğine sahiptirler (Galante ve Formantici, 2003; Buschle ve ark. 1999).

Araştırmacılar tekstil işlemlerinde çevre dostu üretim yaklaşımlarına yönelmiş ve çevre dostu üretimi, enzimlerin kullanımı ile gerçekleştirilebileceğine dair birçok araştırma yapmışlardır. Navone ve arkadaşları yün/polyester kumaş karışımlarının yeniden kullanılabilirliğinde enzimatik işlemlerin uygulanabilirliğini araştırmışlardır. $\mathrm{Bu}$ kapsamda, yün ve polyesteri ayırmak için yün/polyester karışımı kumaş keratinaz enzimi ile muamele edilmiş ve polyester elyaf geri kazandırılmıştır. Bu işlemle polyester elyaf, polyester ipliğe geri dönüştürülmeye ve yeni giysilerin imaltında kullanılmaya uygun hale getirilmiştir. Enzimatik işlemle ortaya çıkan keratin hidrolizat ise gübre ve hayvan yemi olarak kullanılabileceği sonucuna varılmıştır (Navone ve ark. 2020). Bir diğer çalışmada oldukça hidrofobik olan indigo karmin boyanın boya sonrası banyoda lakkaz enzimi ile parçalanması incelenmiştir. Elde edilen sonuçlara göre enzimlerin farklı yüzey aktif madde esaslı iyonik sıvılarla birlike hidrofobik boyaların parçalanmasını iyileştirdiği sonucuna varılmıştır (Bento ve ark. 2020). Fritzke ve arkadaşları sedir ağacı yaprağı peroksidaz enzimini karakterize etmişler ve tekstil sektöründende kullanılan boyaların parçalanmasında kullanımını araşııımışlardır. Elde edilen enzimin $50{ }^{\circ} \mathrm{C}-62{ }^{\circ} \mathrm{C}$ ve $\mathrm{pH} 5$ 'de gayakolun substrat olarak kullanımında en yüksek aktiviteyi sergilediği sonucuna varılmıştır. Sedir yaprağı peroksidaz enziminin, tekstil boyaları içeren atık suların arıtılması için bir alternatif olabileceği belirtilmiştir (Fritzke ve ark. 2020). Parajapati ve arkadaşları yün/polyester kumaş karışımına dekoratif efekt vermek için protaz enzimini kullanmışlardır. Kontrollü protaz enzimi işlemi, boyanmış yün/polyester kumaş karışımından yün elyafının uzaklaştırılmasını sağlamış ve kumaşda dekoratif bir efekt meydana getirmiştir. İşlem sonunda karışım kumaştaki yün elyafının \%85'i uzaklaştııılmıştır (Prajapati ve ark. 2019). Bu çalışmalara ek olarak rami lifinin hidrofilleştirilmesinde ksilen-pektinolitik (Singh ve ark. 2020), keten lifinin eldesinde Aspergillus niger ve ksilen (De Prez ve ark. 2019), polyesterin polietilen taraftalat ve etilen glikole ayrılmasında Humicola insolens enzimi (Quartinello ve ark. 2017), ve boyarmaddelerin bozunmasında peroksidaz enzimi kullanılmıştır (Baumer ve ark. 2018).

Ultrasonik ses dalgaları $20 \mathrm{kHz}-20 \mathrm{MHz}$ arasındaki frekanslara sahiptir. Ultrasonik enerjinin gücü, kimyasal etkisini kavitasyon yoluyla ortaya çıkarır. Herhangi bir ses dalgası gibi ultrasonik enerji de dalgalar yolu ile iletilmektedir. Bu dalgalar içinden geçmekte olduğu ortamın molekül yapısında sıkışma ve gevşemeler oluşturmaktadır. Sıvıya yeterli miktarda negatif basınç uygulandığında sıvıda parçalanma gözlenir ve kavitasyon baloncukları oluşur. Birbirini takip eden sıkıştırma periyodlarında bu balonlar birbirine çarparak büyük miktarda enerjinin açığa çıkmasına neden olur (Mason, 1998). Tekstil yaş işlemlerinde ultrasonik enerjinin kullanımı, işlem süresi, enerji ve kimyasal maddelerin tasarrufu ve ürün kalitesinin arttırılması açısından yarar sağlamaktadır. Katı/sıvı ara yüzeyde oluşan kavitasyon neticesinde sıvıdan katıya doğru kütle transferinde artı̧̧ olmaktadır (Duran ve ark. 2006).

Ultrasonik enerjinin haşıl banyoları ve emülsiyon patlarının hazırlanmasında, haşıl sökme, bazik işlem ve ağartma işlemlerinde, boyama ve son yıkamalarda, enzimatik işlemlerde kullanılabilirliğine dair araştırmalar devam etmektedir. Ultasonik yöntemde hidrojen peroksit ağartmasında işlem süresinin azaldığı ve beyazlık derecesinin düşük sıcaklıklarda çalışmaya rağmen arttığı (Mistik ve Yükseloglu, 2005), ham pamuğun pektinaz ile biyo temizlenmesinde malzemenin kopma dayanımı, sslanabilirlik ve beyazlık derecesi üzerinde sonikasyonun olumlu etkileri olduğu (Yachmenev ve ark. 2001), klasik ve ultrasonik yöntem kombinasyonunun enzim tüketimini, işlem süresini ve lif hasarını azalttığı, ultrasonik enerjinin pamuğun enzimatik ön işlemlerinde kumaş dayanımını azaltmaksızın enzim etkisini önemli ölçüde geliştirdiği (Yachmenev ve ark. 1998; Karaboğa ve ark. 2007; Yachmenev ve ark. 2004) belirtilmektedir.

$\mathrm{Bu}$ çalışmada enzimatik işlem pamuklu kumaş numunelerine boyamadan önce, boyama esnasında ve boyama işleminden sonra uygulanmıştır. Selülaz enzimi uygulanmış numunelere, enzimatik işlemden sonra klasik ve ultrasonik enerji yöntemi ile yıkamalar yapılmıştır. $\mathrm{Bu}$ işlemlerden sonra numunelerin beyazlık dereceleri, renk ölçümleri, yıkama, sürtünme ter ve $1 s ̧ ı$ haslığı ve boncuklanma özellikleri incelenmiştir.

\section{Materyal ve Metot}

\subsection{Kumaş}

$\mathrm{Bu}$ çalı̧̧mada \%100 pamuk ipliğinden elde edilen pamuklu kumaş numuneleri kullanılmıştır. Kumaş özellikleri Tablo 1'de verilmiştir.

Tablo 1. Çalışmada Kullanılan Kumaşların Özellikleri

\begin{tabular}{l|c|c|c}
\hline Örgü Tipi & Gramaj $\left(\mathbf{g} / \mathbf{m}^{2}\right)$ & Atkı ve Çözgü İplik No & Atkı ve Çözgü Sıklıkları \\
\hline Dimi $3 / 1 \mathrm{Z}$ & 270 & $\mathrm{Ne} 10 / 2$ & $11 \mathrm{tel} / \mathrm{cm}$ \\
\hline Dimi $2 / 1 \mathrm{Z}$ & 272 & $\mathrm{Ne} 10 / 2$ & $11 \mathrm{tel} / \mathrm{cm}$ \\
\hline
\end{tabular}




\subsection{Enzimatik İşlem}

Numunelere boyamadan önce, boyama esnasında ve boyamadan sonra enzimatik işlem uygulanmıştır. Enzimatik işlem, 2 g/L selülaz enzimi (Megenzim-6, Meg Kimya San ve Tic A.Ş.) ile pH 5'de 1:10 flotte oranında gerçekleştirilmiş olup işlem koşulları Şekil 1 'de verilmiştir. Bütün uygulamalarda işlemin tekrarlanabilirliği için her uygulamaya ait üç tekrar yapılmıştır.

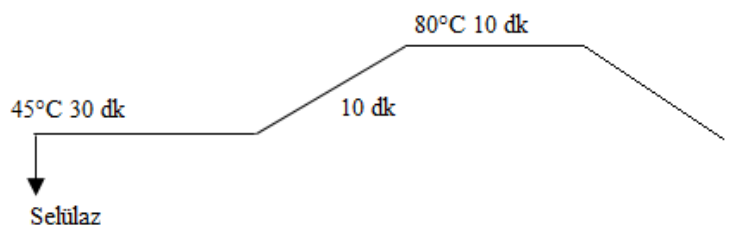

\subsection{Boyama İşlemi}

Şekil 1. Enzimatik işlem sıcaklık-zaman diyagramı

Numuneler reaktif boya ile laboratuvar tipi HT boyama makinesinde boyanmıştır. Boyama işleminde \%4 reaktif boyarmadde (Sunfix Blue RSP-4, Birkim Kimya San ve Tic A.Ş.), 180 g/L sodyum sülfat ve 120 g/L sodyum karbonat kullanılmıştır. Boyama diyagramı Şekil 2'de verilmiştir.

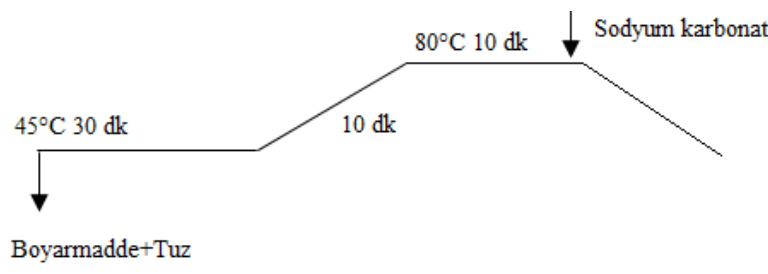

Şekil 2. Boyama diyagramı

\subsection{Yıkama İşlemi}

Numunelere boyama işleminden sonra Tablo 2'de belirtilen koşullarda yıkama işlemi yapılmıştır. Yıkama işlemi konvansiyonel metot ve ultrasonik enerji yardımıyla olmak üzere iki farklı yöntemle gerçekleştirilmiştir.

Tablo 2. Yıkama İşlemi Koşulları

\begin{tabular}{c|c|c}
\hline & Son işlemler & Koşullar \\
\hline 1 & Soğuk su ile durulama & $6 \mathrm{~L} / 5 \mathrm{~g}$ materyal \\
\hline 2 & Asetik asitle nötralizasyon & $\mathrm{pH} 7$ \\
\hline 3 & Sicak su ile durulama & $1000 \mathrm{~mL} / 5 \mathrm{~g}$ materyal \\
\hline 4 & Kaynar sabunlama & $95^{\circ} \mathrm{C}-2 \mathrm{dk}-1000 \mathrm{~mL} / 5$ g materyal \\
\hline 5 & Soğuk su ile durulama & $1000 \mathrm{~mL} / 5 \mathrm{~g}$ materyal \\
\hline
\end{tabular}

\subsection{Beyazlık Derecesi Ölçümü}

Numunelerin beyazlık derecesi Macbeth Color Eye (Gretag Machbeth) spektrofotometresi ile 400-700 nm dalgaboyları için 10 $\mathrm{nm}$ ara 3 tekrarlı olarak gerçekleştirilmiştir.

\subsection{Renk Ölçümü}

Boyanmış örneklerin renk ölçümleri Datacolor SF 600 Renk Ölçüm Cihazı ile Datamaster bilgisayar programı kullanılarak CIELab sistemine göre gerçekleştirilmiştir. Ölçümler, D ${ }_{65}$ illuminatı altında $10^{\circ}$ standart gözlemci kullanılarak gerçekleştirilmiştir.

\subsection{Renk Haslığı Ölçümleri}

Boyanmış numunelerin yıkama haslıkları, ISO 105-C06 standardına göre gerçekleștirilmiş ve gri skala ile değerlendirilmiştir. 1-5 arasında yıkama haslık notu değerlendirilmesinde "5" en iyi değeri karşılamaktadır. Numunelerin ter haslıkları ISO 105 E04 standardına göre gerçekleştirilmiştir. Numunelerin 1şık haslığı tayini, EN ISO 105-B02 standardına göre Atlas Alfa 150S test cihazında, sürtme haslığı ise ISO 105X12 standardına göre H.Heal 255 sürtme test cihazında gerçekleştirilmiştir.

\subsection{Boncuklanma Ölçümü}

Kumaşların boncuklanma derecesi TS EN ISO 12945-2 standardına göre Martindale test cihazında 5 tekrarlı yapılmıştır [16]. 


\section{Araştırma Sonuçları ve Tartışma}

\subsection{Beyazlık Derecesi Öıçüm Sonuçları}

Numunelerin beyazlık derecesi ölçümü 400-700 nm dalga boyları için $10 \mathrm{~nm}$ ara ile spektrofotometrede gerçekleştirilmiştir. Numunelerin spektrofotometrede ölçülen remisyon değerleri yardımıyla Berger Beyazlık Indeksi Formülüne göre (Davulcu, 2008) beyazlık dereceleri hesaplanmıştır. Numunelerin beyazlık derecesi Şekil 3'de verilmiştir.

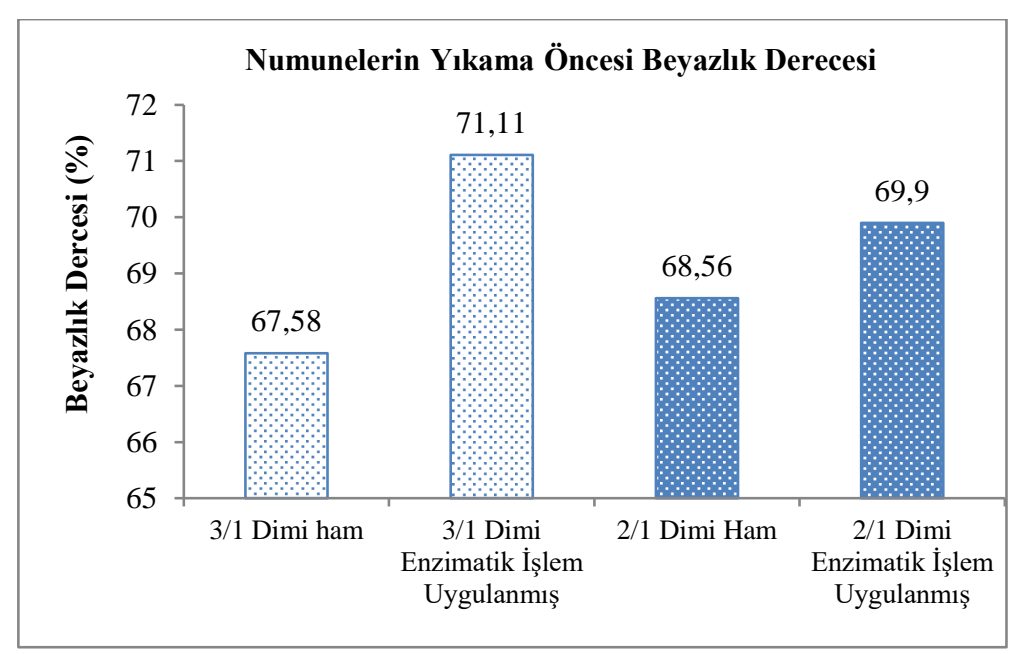

Şekil 3. Boyama öncesi enzim uygulaması yapılmış ve yapılmamış numunelerin beyazlık dereceleri

Beyazlık derecesi ölçümü sonuçları enzimatik işlem uygulamasıyla numunelerin beyazlık derecesinde artış olduğunu göstermektedir. Enzimatik işlem uygulaması ile birlikte pamuklu kumaş numunelerinde bulunan renkli yabancı maddeler enzimler vasıtasıyla parçalanıp uzaklaştırılmaktadır. Ağartma işleminde sıklıkla kullanılan sodyum hipoklorit, sodyum hidroksit, hidrojen peroksit, asitler, yüzey aktif maddeler, sodyum silikat, ve sodyum fosfat gibi kimyasallar atık suya yüksek oranda kimyasal madde bırakmaktadır. Tekstil ağartma işlemlerinde bu kimyasal maddelere ikame olarak enzim kullanımı, işlem türüne bağlı olarak su tüketimini ve hava emisyonunu azaltmaktadır. Böylece ekolojik üretim yanında maliyetler de azalmaktadır (İnkaya ve ark. 2010). Beyazlık derecesi kumaş deseni açısından incelendiğinde dimi 3/1 numunelerin beyazlık derecesi dimi 2/1 numunelerin beyazlık derecesinden daha yüksektir. Bu sonuç üzerinde iki kumaş arasındaki iplik yüzme miktarı farklılığının neden olduğu düşünülmektedir. Ayrıca 3/1 dimi deseninde atlama sayılarının daha fazla olması ve selülaz enziminin kumaş içine daha kolay nüfuz edebilmesi nedeni ile en fazla beyazlık derecesi artışının dimi 3/1 kumaşta olduğu belirlenmiştir.

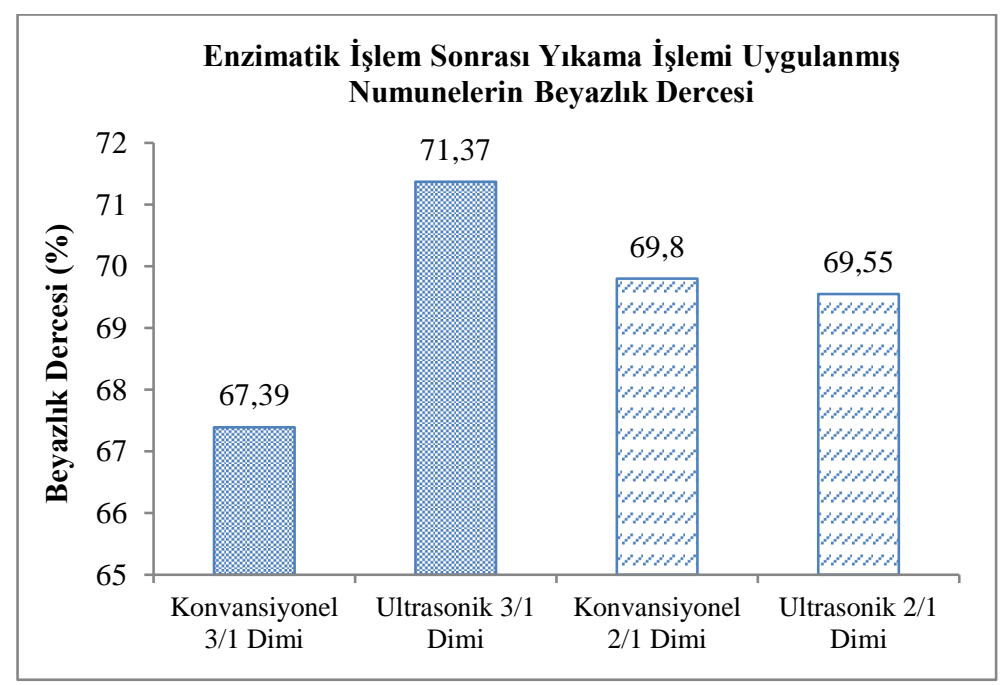

Şekil 4. Konvansiyonel ve ultrasonik enerji yardımılla yıkanmış numunelerin beyazlık derecesi

Enzimatik işlem sonrasında konvansiyonel ve ultrasonik enerji yardımıyla yıkanan numunelerin beyazlık derecelerinde artış görülmüştür. Yıkama işlemi, enzimatik işlem ile numunelerden kopartılan ancak numuneler üzerinde kalan renkli pigmentleri uzaklaştırdığı düşünülmektedir. Konvansiyonel ve ultrasonik yıkama yöntemleri karşılaştırıldığında beyazlık derecesi üzerine ultrasonik yıkama yönteminin konvansiyonel yönteme göre daha etkili olduğu sonucuna varılmıştır. Ultrasonik yıkamada ses dalgaları ile yıkama banyosunda kavitasyonlar oluşturulmakta ve bu kavitasyonların mamul üzerinden yabancı maddeleri uzaklaştırmada konvansiyonel ısıtmaya göre daha etkili olduğu düşünülmektedir. 


\subsection{Renk Ölçüm Sonuçları}

Boyama işlemi sonrası konvansiyonel ve ultrasonik enerji yardımıyla yıkanmış numunelerin spektrofotometrik ölçüm sonuçları (CIELab değerleri) Şekil 5 ve Şekil 6 'da verilmiştir. Ölçümlerde enzimatik işlem uygulanmamış, boyanmış ve konvansiyonel yıkama yapılmış numune standart numune olarak kabul edilmiştir.

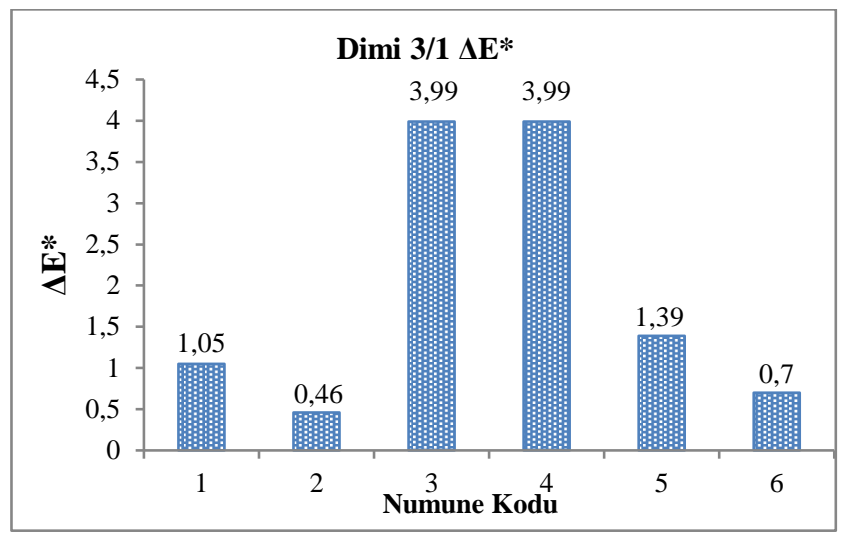

(a)

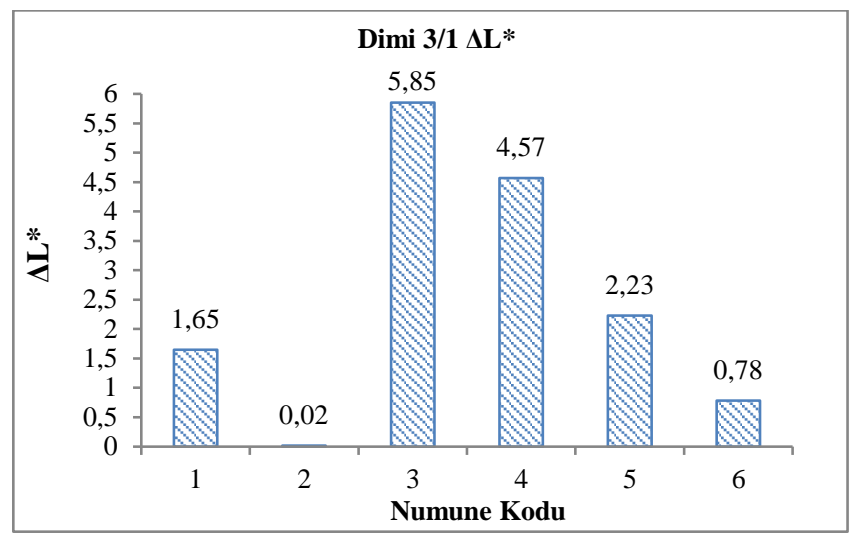

(b)

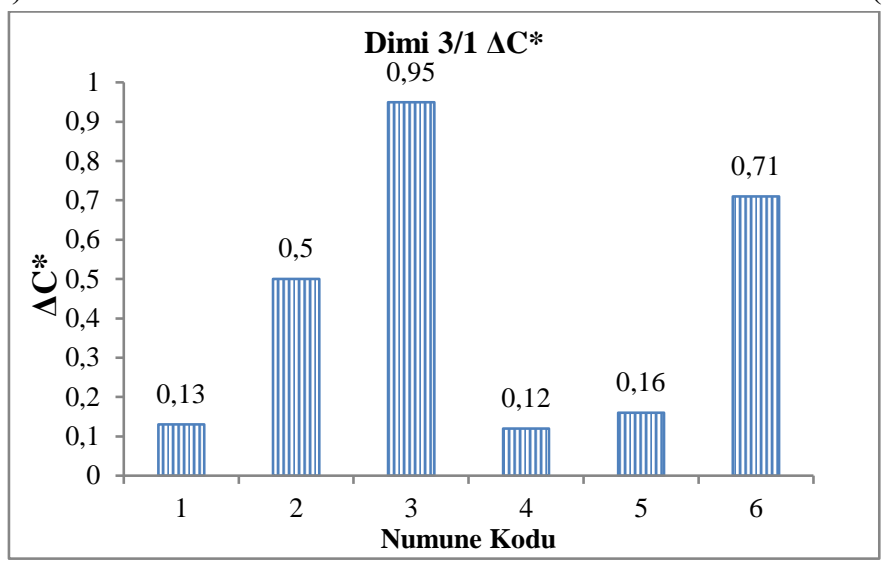

(c)

1.Enzimatik işlem $\rightarrow$ boyama $\rightarrow$ konvansiyonel yıkama

2. Enzimatik işlem $\rightarrow$ boyama $\rightarrow$ ultrasonik yıkama

3. Boyama anında enzimatik işlem $\rightarrow$ konvansiyonel yıkama
4. Boyama anında enzimatik işlem $\rightarrow$ ultrasonik yıkama

5. Boyama $\rightarrow$ enzimatik işlem $\rightarrow$ konvansiyonel yıkama

6. Boyama $\rightarrow$ enzimatik işlem $\rightarrow$ ultrasonik yıkama

\section{Şekil 5. Numunelerin spektrofotometrik ölçüm sonuçları: (a)Dimi 3/1 kumaş numunelerinin $\Delta E^{*}$ değerleri,(b)Dimi 3/1 kumaş} numunelerinin $\Delta L^{*}$ değerleri, (c)Dimi $3 / 1$ kumaş numunelerinin $\Delta C^{*}$ de ğerleri

Dimi 3/1 desenindeki kumaş numunelerinin kolorimetrik ölçümlerinde enzimatik işlem uygulanmamış, boyanmış ve konvansiyonel yıkama yapılmış numune standart numune olarak kabul edilmiştir. Ölçümlerde $\Delta \mathrm{E}^{*}$ değeri toplam renk farklılığını ifade etmektedir. $\Delta \mathrm{E}^{*}<1$ ise, standart numune ile ölçüm yapılan numune arasında renk farklılığı çok az; $\Delta \mathrm{E}^{*}>1$ ise standart numune ile ölçüm yapılan numune arasında renk farklılığı çok fazladır. Şekil (a) incelendiğinde standart numune ile diğer numuneler arasındaki farkın fazla olduğu belirlenmiştir. Ölçümlerde $\Delta \mathrm{L}^{*}$ değerlerinin (-) olması, örneğin standarda göre daha koyu olduğunu, $(+)$ olması ise daha açık olduğunu ifade etmektedir. Buna göre; bütün boyanmış numunelerin rengi standart numunenin renginden daha açık renktedir. $\Delta C^{*}$ değerinin $(+)$ olması ise yüksek kromayı yani doygunluğu ifade eder. Tüm numunelerde doygunluk değerinin yüksek olduğu belirlenmiştir. Enzimler lifin yapısındaki bağları hidrolize eden biyokatalizörlerdir. Selülaz enziminin pamuk lif yapısında gevşemelere neden olarak boyarmadde moleküllerinin lif içine difüzyonunu kolaylaştırdığı düşünülmektedir. Böylece standart numune ile diğer numuneler arasındaki renk farkı ve doygunluk artmıştır (Atav ve ark. 2014; Mavruz ve Oğulata, 2007). 


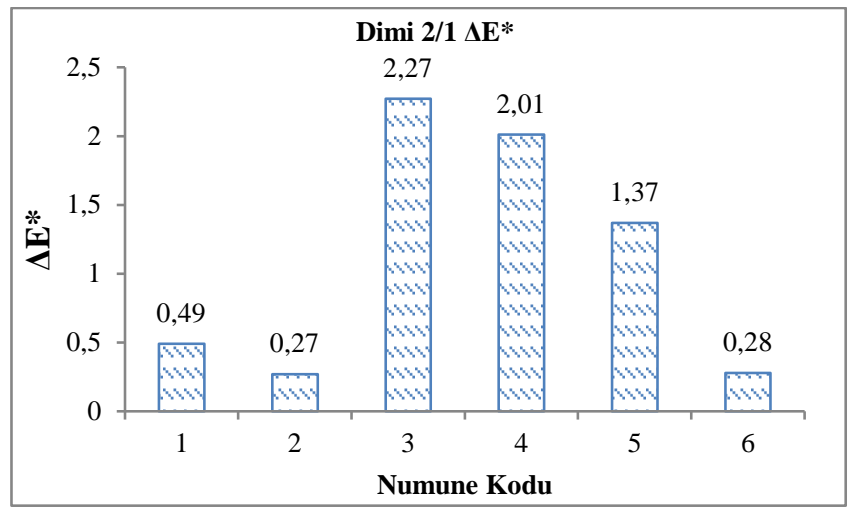

(a)

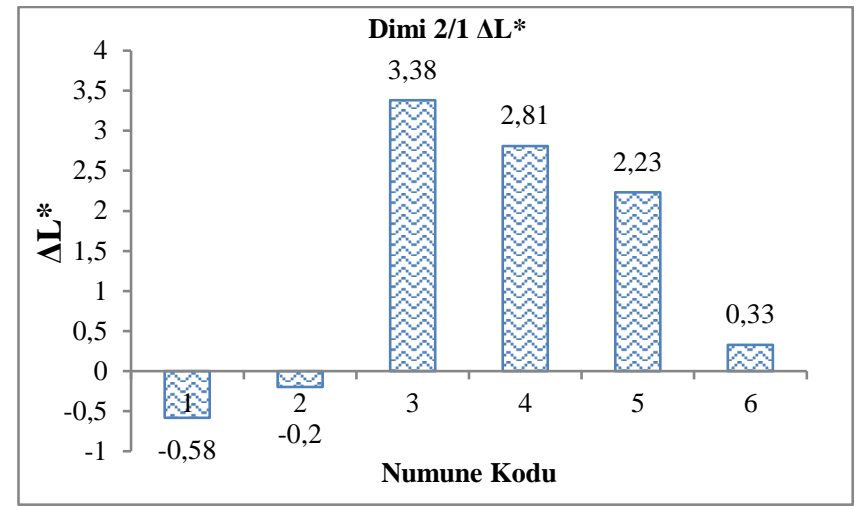

(b)

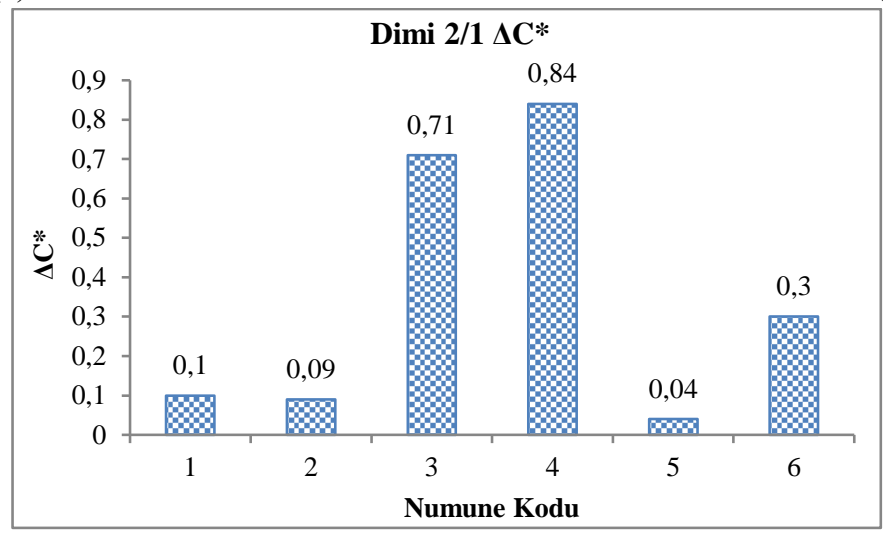

(c)

1.Enzimatik işlem $\rightarrow$ boyama $\rightarrow$ konvansiyonel yıkama

2. Enzimatik işlem $\rightarrow$ boyama $\rightarrow$ ultrasonik yıkama

3. Boyama anında enzimatik işlem $\rightarrow$ konvansiyonel yıkama
4. Boyama anında enzimatik işlem $\rightarrow$ ultrasonik yıkama

5. Boyama $\rightarrow$ enzimatik işlem $\rightarrow$ konvansiyonel yıkama

6. Boyama $\rightarrow$ enzimatik işlem $\rightarrow$ ultrasonik yıkama

Şekil 6. Numunelerin spektrofotometrik ölçüm sonuçları: (a) Dimi 2/1 kumaş numunelerinin $\Delta E^{*}$ değerleri,(b) Dimi 2/1 kumaş numunelerinin $\Delta L^{*}$ değerleri, (c)Dimi 2/1 kumaş numunelerinin $\Delta C^{*}$ değerleri

Dimi 2/1 desenindeki kumaş numunelerinin kolorimetrik ölçümlerinde enzimatik işlem uygulanmamış, boyanmış ve konvansiyonel yıkama yapılmış numune standart olarak kabul edilmiştir. Ölçümlerde $\Delta \mathrm{E}^{*}$ değeri toplam renk farklılığını ifade etmekte olup; $\Delta \mathrm{E}^{*}<1$ ise, standart numune ile ölçüm yapılan numune arasında renk farklılığı çok az; $\Delta \mathrm{E}^{*}>1$ ise çok fazladır. Kolorimetrik ölçümlerde standart numune ile diğer numuneler arasındaki farkın fazla olduğu belirlenmiştir. Ölçümlerde $\Delta \mathrm{L}^{*}$ değerlerinin (-) olması, örneğin standarda göre daha koyu olduğunu, $(+)$ olması ise daha açık olduğunu ifade etmektedir. Buna göre; 1 ve 2 numaralı numunelerin rengi standart numunenin renginden daha koyu, 3,4,5 ve 6 numaralı numuneler daha açık renktedir. $\Delta \mathrm{C}^{*}$ değerinin (+) olması ise yüksek kromayı yani doygunluğu ifade eder. Tüm numunelerde doygunluk değerinin yüksek olduğu belirlenmiştir.

\subsection{Haslık Ölçüm Sonuçları}

Bu çalışmada numunelerin yıkama, sürtünme, ter ve 1şık haslıkları ISO standartlarına göre test edilmiş ve gri skala yardımı ile değerlendirilmiş ve sonuçlar Tablo 3'de verilmiştir. Ölçümlerde enzimatik işlem uygulanmamış, boyanmış ve konvansiyonel yıkama yapılmış numune standart numune olarak kabul edilmiştir. 
Tablo 3. Numunelerin Ylkama, Sürtme, Ter ve Işık Haslığı Değerleri

\begin{tabular}{|c|c|c|c|c|c|}
\hline \multicolumn{6}{|c|}{ Standart numune $\rightarrow$ Konvansiyonel yıkama } \\
\hline \multicolumn{6}{|c|}{ Dimi 2/1 } \\
\hline \multirow[t]{2}{*}{ Yıkama } & \multicolumn{2}{|c|}{ Sürtme } & \multicolumn{2}{|c|}{ Ter } & Işılk \\
\hline & kuru & yaş & asidik & bazik & \\
\hline $3-4$ & 4 & 3 & $4-5$ & 5 & $4-5$ \\
\hline \multicolumn{6}{|c|}{ Standart numune $\rightarrow$ Konvansiyonel yıkama } \\
\hline \multicolumn{6}{|c|}{ Dimi 2/1 } \\
\hline \multirow[t]{2}{*}{ Yıkama } & \multicolumn{2}{|c|}{ Sürtme } & \multicolumn{2}{|c|}{ Ter } & Işılk \\
\hline & kuru & yaş & asidik & bazik & \\
\hline 4 & $4-5$ & 3 & 4 & 5 & $4-5$ \\
\hline \multicolumn{6}{|c|}{ Standart numune $\rightarrow$ Ultrasonik yıkama } \\
\hline \multicolumn{6}{|l|}{ Dimi 2/1 } \\
\hline \multirow[t]{2}{*}{ Yıkama } & \multicolumn{2}{|c|}{ Sürtme } & \multicolumn{2}{|c|}{ Ter } & Işılk \\
\hline & kuru & yaş & asidik & bazik & \\
\hline 4 & $4-5$ & 3 & 4 & 5 & $4-5$ \\
\hline
\end{tabular}

Standart numune $\rightarrow$ Ultrasonik yıkama

Dimi 3/1

\begin{tabular}{c|c|c|c|c|c}
\hline Yıkama & Sürtme & Ter & Işık & & \\
\hline 4 & kuru & yaş & asidik & bazik & \\
\hline Enzimatik işlem $\rightarrow$ Boyama $\rightarrow$ Konvansiyonel yıkama \\
\hline Dimi 2/1 Sürtme & $4-5$ & 4 & $4-5$ & 5 & 4 \\
\hline Yıkama & \multicolumn{7}{c}{ Ter } & Işı k \\
\hline \multicolumn{7}{c}{ kuru } & yaş & asidik & bazik & $4-5$ \\
\hline 4 & 4 & $3-4$ & 5 & 5 &
\end{tabular}

Enzimatik işlem $\rightarrow$ Boyama $\rightarrow$ Konvansiyonel yıkama

Dimi 3/1

\begin{tabular}{c|c|c|c|c|c}
\hline Yıkama & \multicolumn{2}{|c|}{ Sürtme } & \multicolumn{2}{c|}{ Ter } & Işıı \\
\hline & kuru & yaş & asidik & bazik & \\
\hline $3-4$ & $3-4$ & 3 & $4-5$ & 4 & $4-5$ \\
\hline Enzimatik ișlem $\rightarrow$ Boyama $\rightarrow$ Ultrasonik yıma & & &
\end{tabular}

Enzimatik işlem $\rightarrow$ Boyama $\rightarrow$ Ultrasonik yıkama

Dimi 2/1

\begin{tabular}{c|c|c|c|c|c}
\hline Yıkama & \multicolumn{2}{|c|}{ Sürtme } & \multicolumn{2}{c|}{ Ter } & Işık \\
\hline & kuru & yaş & asidik & bazik & \\
\hline $5-4$ & $5-4$ & 4 & 5 & 5 & $4-5$ \\
\hline
\end{tabular}

Enzimatik işlem $\rightarrow$ Boyama $\rightarrow$ Ultrasonik yıkama

Dimi 3/1

\begin{tabular}{c|c|c|c|c|c}
\hline Yıkama & \multicolumn{2}{|c|}{ Sürtme } & \multicolumn{2}{c}{ Ter } & Işıı \\
\hline & kuru & yaş & asidik & bazik & \\
\hline $5-4$ & $5-4$ & 4 & $4-5$ & $4-5$ & 5 \\
\hline Boyama anında enzimatik ișlem $\rightarrow$ Konvansiyonel yıkama
\end{tabular}

Boyama anında enzimatik ișlem $\rightarrow$ Konvansiyonel yıkama

Dimi 2/1

\begin{tabular}{c|c|c|c|c|c}
\hline Yıkama & \multicolumn{2}{|c|}{ Sürtme } & \multicolumn{2}{c|}{ Ter } & Işı̀ \\
\hline & kuru & yaş & asidik & bazik & \\
\hline 4 & $4-5$ & $3-4$ & 5 & 5 & 4 \\
\hline
\end{tabular}

Boyama anında enzimatik işlem $\rightarrow$ Konvansiyonel yıkama

Dimi 3/1

\begin{tabular}{c|c|c|c|c|c}
\hline Yıkama & \multicolumn{2}{|c|}{ Sürtme } & \multicolumn{2}{c|}{ Ter } & Iş̧ı \\
\hline & kuru & yaş & asidik & bazik & \\
\hline $4-5$ & 4 & 4 & $4-5$ & $4-5$ & 4 \\
\hline
\end{tabular}

Boyama anında enzimatik işlem $\rightarrow$ Ultrasonik yıkama

Dimi 2/1

\begin{tabular}{c|c|c|c|c|c}
\hline Yıkama & \multicolumn{2}{|c|}{ Sürtme } & \multicolumn{2}{c|}{ Ter } & Işık \\
\hline 5 & kuru & yaş & asidik & bazik & \\
\hline 5 & $4-5$ & $4-5$ & 5 & 5 & $4-5$ \\
\hline
\end{tabular}

Boyama anında enzimatik işlem $\rightarrow$ Ultrasonik Yıkama

Dimi 3/1 


\begin{tabular}{|c|c|c|c|c|c|}
\hline \multirow[t]{2}{*}{ Yıkama } & \multicolumn{2}{|c|}{ Sürtme } & \multicolumn{2}{|c|}{ Ter } & \multirow[t]{2}{*}{ Işıı } \\
\hline & kuru & yaş & asidik & bazik & \\
\hline 5 & 4 & $4-5$ & $4-5$ & 5 & 5 \\
\hline \multicolumn{6}{|c|}{ Boyama $\rightarrow$ Enzimatik işlem $\rightarrow$ Konvansiyonel yıkama } \\
\hline \multicolumn{6}{|c|}{ Dimi 2/1 } \\
\hline \multirow[t]{2}{*}{ Yıkama } & \multicolumn{2}{|c|}{ Sürtme } & \multicolumn{2}{|c|}{ Ter } & Işık \\
\hline & kuru & yaş & asidik & bazik & \\
\hline 4 & $4-5$ & 4 & 5 & 5 & $4-5$ \\
\hline \multicolumn{6}{|c|}{ Boyama $\rightarrow$ Enzimatik işlem $\rightarrow$ Konvansiyonel yıkama } \\
\hline \multicolumn{6}{|c|}{ Dimi 3/1 } \\
\hline \multirow[t]{2}{*}{ Yıkama } & \multicolumn{2}{|c|}{ Sürtme } & \multicolumn{2}{|c|}{ Ter } & Işık \\
\hline & kuru & yaş & asidik & bazik & \\
\hline 4 & $4-5$ & 4 & 5 & 5 & $4-5$ \\
\hline \multicolumn{6}{|c|}{ Boyama $\rightarrow$ Enzimatik işlem $\rightarrow$ Ultrasonik yıkama } \\
\hline \multicolumn{6}{|c|}{ Dimi 2/1 } \\
\hline \multirow[t]{2}{*}{ Yıkama } & \multicolumn{2}{|c|}{ Sürtme } & \multicolumn{2}{|c|}{ Ter } & Işsık \\
\hline & kuru & yaş & asidik & bazik & \\
\hline $4-5$ & 5 & $4-5$ & 5 & 5 & $4-5$ \\
\hline \multicolumn{6}{|c|}{ Boyama $\rightarrow$ Enzimatik işlem $\rightarrow$ Ultrasonik yıkama } \\
\hline \multicolumn{6}{|c|}{ Dimi 3/1 } \\
\hline \multirow[t]{2}{*}{ Yıkama } & \multicolumn{2}{|c|}{ Sürtme } & \multicolumn{2}{|c|}{ Ter } & Işık \\
\hline & kuru & yaş & asidik & bazik & \\
\hline 5 & 5 & $4-5$ & 5 & 5 & 5 \\
\hline
\end{tabular}

Tablo 3 incelendiğinde, kumaş deseninin numunelerin yıkama, sürtünme, ter ve 1şık haslığı üzerinde etkili olmadığı belirlenmiştir. Boyamalarda enzimatik işlemin uygulanma şeklinin yıkama, sürtünme, ter ve 1şık haslığı üzerine çok fazla etkili olmadığı belirlenmiştir. Numunelerin haslık değerleri yıkama yöntemi açısından incelendiğinde yıkama yönteminin numunelerin haslık değerleri üzerinde etkili olduğu görülmüştür. Ultrasonik enerjinin kullanıldı̆̆ı yıkamalarda yıkama flottesine, ultrasonik enerji uygulanmakta ve yıkama ultrasonik enerji yardımıyla gerçekleştirilmektedir. Flotte ultrasonik enerji yardımıyla 1sıtılmakta ve harekete geçirilmektedir. Konvansiyonel yöntemle yıkamanın tersine flottede daha homojen bir ısıtma ve karıştırma sağlamaktadır. Konvansiyonel yıkamada flotte alttan 1sıtıcı vasıtasıyla 1sıtılmakta ve flotte manuel olarak karıştırılmaktadır. Yıkama banyosunun belirli bir sıcaklığa ulaşması için geçen süre ultarsonik enerjinin kullanımına kıyasla çok daha uzundur. Manuel karıştırma ve uzun süreli işlem nedeniyle boyarmadde ve lif arasındaki fiziksek bağların zayıflaması nedeniyle haslık değerleri konvansiyonel yıkamalarda daha düşüktür.

\subsection{Boncuklanma Ölçüm Sonuçları}

Martindale boncuklanma testi 5 ölçümün ortalaması alınarak yapılmış olup, test sonuçları Tablo 4' de verilmiştir. Ölçümlerde enzimatik işlem uygulanmamış, boyanmış ve konvansiyonel yıkama yapılmış numune standart numune olarak kabul edilmiştir. 
Tablo 4. Numunelerin Boncuklanma Değerleri

\begin{tabular}{|c|c|c|c|c|}
\hline \multirow[b]{2}{*}{$125 \mathrm{dev} / \mathrm{dak}$} & \multicolumn{2}{|c|}{ Dimi 3/1 } & \multicolumn{2}{|c|}{ Dimi 2/1 } \\
\hline & $\begin{array}{l}\text { Konvansiyonel } \\
\text { yıkama }\end{array}$ & $\begin{array}{l}\text { Ultrasonik } \\
\text { yıkama }\end{array}$ & $\begin{array}{l}\text { Konvansiyonel } \\
\text { yıkama }\end{array}$ & $\begin{array}{l}\text { Ultrasonik } \\
\text { yıkama }\end{array}$ \\
\hline Standart Numune & 4 & $4-5$ & $4-5$ & $4-5$ \\
\hline Enzimatik işlem $\rightarrow$ Boyama $\rightarrow$ Konvansiyonel yıkama & 5 & 5 & 5 & 5 \\
\hline $\begin{array}{l}\text { Boyama anında enzimatik işlem } \rightarrow \text { Konvansiyonel } \\
\text { yıkama }\end{array}$ & 5 & 5 & 5 & 5 \\
\hline Boyama $\rightarrow$ Enzimatik işlem $\rightarrow$ Konvansiyonel yıkama & 5 & 5 & 5 & 5 \\
\hline \multicolumn{5}{|l|}{$500 \mathrm{dev} / \mathrm{dak}$} \\
\hline Standart Numune & 4 & 5 & $4-5$ & 5 \\
\hline Enzimatik işlem $\rightarrow$ Boyama $\rightarrow$ Konvansiyonel yıkama & 5 & 5 & 5 & 5 \\
\hline $\begin{array}{l}\text { Boyama anında enzimatik işlem } \rightarrow \text { Konvansiyonel } \\
\text { yıkama }\end{array}$ & 5 & 5 & 5 & 5 \\
\hline Boyama $\rightarrow$ Enzimatik işlem $\rightarrow$ Konvansiyonel yıkama & 5 & 5 & 5 & 5 \\
\hline \multicolumn{5}{|l|}{$2000 \mathrm{dev} / \mathrm{dak}$} \\
\hline Standart Numune & $1-2$ & 2 & $2-3$ & 3 \\
\hline Enzimatik işlem $\rightarrow$ Boyama $\rightarrow$ Konvansiyonel yıkama & 4 & 5 & 5 & 5 \\
\hline $\begin{array}{l}\text { Boyama anında enzimatik işlem } \rightarrow \text { Konvansiyonel } \\
\text { yıkama }\end{array}$ & 4 & 5 & 5 & 5 \\
\hline Boyama $\rightarrow$ Enzimatik işlem $\rightarrow$ Konvansiyonel yıkama & 4 & 5 & 5 & 5 \\
\hline
\end{tabular}

Tablo 4' de numunelerin 125, 500 ve 2000 devirdeki boncuklanma değerleri yer almaktadır. Kumaşların boncuklanma dereceleri incelendiğinde selülaz enzimi ile işlem gören bütün numunelerin boncuklanma sonuçları enzimatik işleme tabi tutulmamış numuneden daha yüksek değerde olduğu sonucuna varılmıştır. Ayrıca Martindale test cihazında devir sayısı artışı ile numunelerin boncuklanma eğiliminde dikkate değer bir düşüş gözlenmemiştir. Enzimatik işlem uygulaması ile numunelerin yüzeyinden tüycüklerin uzaklaştırılması sonucu numunelerin boncuklanma değerinde iyileşme belirlenmiştir. Devir sayısı artışı ile standart numunenin boncuklanma değeri oldukça azalırken, diğer numunelerin boncuklanma eğiliminde dikkate değer bir düşüşe rastlanılmamıştır. Ayrıca enzimatik işlemin uygulanma sırası ve işlemlerden sonra yıkama şeklinin numunelerin boncuklanma değeri üzerinde etkili olmadığı belirlenmiştir (Mavruz ve Oğulata, 2007).

\section{Sonuç}

Enzimatik işlemin pamuklu kumaş numunelerine boyamadan önce, boyama esnasında ve boyama işleminden sonra uygulandığı bu çalışmada, enzimatik işlemin uygulanma ve yıkama şeklinin beyazlık derecesi, renk değeri, yıkama, sürtme, ter ve ışık haslığı ve boncuklanma derecesi üzerine etkisi araştırılmıştır. Numunelere enzim uygulamalarında; kumaşların beyazlık dereceleri karşılaştırıldığında enzimatik işlemin kumaşların beyazlık derecesini olumsuz yönde etkilemediği gibi, beyazlık derecesinde bütün kumaş tiplerinde artış gözlemlenmiştir. Ayrıca hem klasik hem de ultrasonik enerji yardımıyla yıkama sonundaki beyazlık dereceleri karşılaştırıldığında ultrasonik enerji yardımı ile yıkamalarda genellikle beyazlık derecesinde artışlar olduğu belirlenmiştir. Kolorimetrik ölçümlerden, standart numune ile diğer numuneler arasındaki farkın fazla olduğu, bütün boyanmış numunelerin renginin standart numunenin renginden daha açık olduğu ve genel olarak numunelerin doygunluk değerinin standart numuneden daha yüksek olduğu sonucuna varılmıştır. Ultrasonik yöntem kullanılarak yapılan yıkama işlemleri sonucunda elde edilen numuneler, klasik yöntemle yapılan yıkamalar sonucunda elde edilen numunelere göre, standart numunenin rengine çok daha yakındır. Numunelerin haslık özellikleri incelendiğinde, kumaş deseninin ve enzimatik işlemin uygulanma şeklinin haslıklar üzerinde etkili olmadığ belirlenmiştir. Numunelerin haslık değerleri yıkama yöntemi açısından incelendiğinde yıkama yönteminin numunelerin haslık değerleri üzerinde etkili olduğu görülmüştür. Numunelerin boncuklanma dereceleri incelendiğinde enzimatik işleme tabi tutulan bütün numunelerin boncuklanma sonuçları enzimatik işleme tabi tutulmamış numuneden daha yüksek değerde olduğu sonucuna varılmıştır.

\section{Kaynakça}

Atav, R., Namırtı, O., \& Karabulut, K. (2014). Enzimatik Ön İşlemin Poliester Liflerinin Düşük Sıcaklıkta Boyanması İçin Kullanılabilirliğinin İncelenmesi. XIII. Uluslararası İzmir Tekstil ve Hazır Giyim Sempozyumu, 2-5 Nisan, İzmir, Türkiye. 
Baumer, J. D., Valério, A., de Souza, S. M. G. U., Erzinger, G. S., Furigo Jr, A., \& de Souza, A. A. U. (2018). Toxicity of enzymatically decolored textile dyes solution by horseradish peroxidase. Journal of hazardous materials, 360, 82-88.

Bento, R. M., Almeida, M. R., Bharmoria, P., Freire, M. G., \& Tavares, A. P. (2020). Improvements in the enzymatic degradation of textile dyes using ionic-liquid-based surfactants. Separation and Purification Technology, 235, 116191.

Buschle-Diller, G., Walsh, W. K., \& Radhakrishnaiah, P. (1999). Effect of Enzymatic Treatment on Dyeing and Finishing of Cellulosic Fibers: A Study of the Basic Mechanisms and Optimization of the Process. National Textile Centre Research Briefs, 35-36.

Davulcu, A. (2008). Pamuklu Kumasların Ön Terbiye Proseslerinin Enzimatik Yöntemlerle Kombine Edilmesi Üzerine Bir Araştırma. Doktora Tezi, Uludağ Üniversitesi, Bursa, Türkiye.

De Prez, J., Van Vuure, A. W., Ivens, J., Aerts, G., \& Van de Voorde, I. (2019). Effect of enzymatic treatment of flax on fineness of fibers and mechanical performance of composites. Composites Part A: Applied Science and Manufacturing, 123, 190-199.

Duran, K., Bahtiyari, M. İ., Körlü, A. E., Dereli, S., \& Özdemir, D. (2006). Ultrasound Technology. Tekstil ve Konfeksiyon, 16(3), 155-158.

Fritzke, W., Salla, E. G., Bagatini, M. D., Bonadiman, B. D. S. R., Skoronski, E., Moroni, L. S., \& Kempka, A. P. (2020). Peroxidase of Cedrela fissilis leaves: Biochemical characterization and toxicity of enzymatically decolored solution of textile dye Brilliant Sky-Blue G. Biocatalysis and Agricultural Biotechnology, 24, 101553.

Galante, Y. M., \& Formantici, C. (2003). Enzyme applications in detergency and in manufacturing industries. Current Organic Chemistry, 7(13), 1399-1422.

İnkaya, T., Eren, H. A., \& Pervin, A. N. İ. Ş. (2010). Pamuk ağartilmasinda lakkaz/mediatör sistemlerinin oksijen ve ozon ile kombine edilmesi. Pamukkale Üniversitesi Mühendislik Bilimleri Dergisi, 14(1), 77-82.

Karaboğa, C., Körlü, A. E., Duran, C., \& Bahtiyari, M. I. (2007). Use of ultrasonic technology in enzymatic pretreatment processes of cotton fabrics. Fibres \& Textiles in Eastern Europe, (4 (63)), 97-100.

Mason, T. J. (1988). Theory. Applications and uses of ultrasound in chemistry. Sonochemistry.

Mavruz, S., \& Oğulata, R. T. (2007). Tekstil Terbiyesinde Biyoparlatma Uygulamaları Ve Pamuklu Örme Kumaşların Bazı Fiziksel Ve Kimyasal Özelliklerine Etkisi. Tekstil ve Mühendis, 14(66), 15-22.

Mistik, S. I., \& Yükseloglu, S. M. (2005). Hydrogen peroxide bleaching of cotton in ultrasonic energy. Ultrasonics, 43(10), 811-814.

Navone, L., Moffitt, K., Hansen, K. A., Blinco, J., Payne, A., \& Speight, R. (2020). Closing the textile loop: Enzymatic fibre separation and recycling of wool/polyester fabric blends. Waste Management, 102, 149-160.

Prajapati, C. D., Smith, E., Kane, F., \& Shen, J. (2019). Selective enzymatic modification of wool/polyester blended fabrics for surface patterning. Journal of cleaner production, 211, 909-921.

Quartinello, F., Vajnhandl, S., Volmajer Valh, J., Farmer, T. J., Vončina, B., Lobnik, A., Acero,H. E., Pellis, A., \& Guebitz, G. M. (2017). Synergistic chemo-enzymatic hydrolysis of poly (ethylene terephthalate) from textile waste. Microbial biotechnology, 10(6), 1376-1383.

Singh, A., Varghese, L. M., Battan, B., Patra, A. K., Mandhan, R. P., \& Mahajan, R. (2020). Eco-friendly scouring of ramie fibers using crude xylano-pectinolytic enzymes for textile purpose. Environmental Science and Pollution Research, 27(6), 6701-6710.

Stöhr, R. (1995). Enzymes-biocatalysts in textile finishing. Melliand Textilberichte International Textile Reports, 76, 1010-1015.

Test for colour fastness of textiles-colour fastness to washing, International Organization for Standardization ISO 105-C06, 1997.

Tests for colour fastness-Colour fastness to artificial light:Xenon arc fading lamp test, International Organization for Standardization, 2014

Tests for colour fastness-Colour fastness to perspiration, International Organization for Standardization, 2006

Tests for colour fastness-Part X12: Colour fastness to rubbing, International Organization for Standardization, 2006

Yachmenev, V. G., Bertoniere, N. R., \& Blanchard, E. J. (2001). Effect of sonication on cotton preparation with alkaline pectinase. Textile Research Journal, 71(6), 527-533.

Yachmenev, V. G., Blanchard, E. J., \& Lambert, A. H. (1998). Use of ultrasonic energy in the enzymatic treatment of cotton fabric. Industrial \& Engineering Chemistry Research, 37(10), 3919-3923.

Yachmenev, V. G., Blanchard, E. J., \& Lambert, A. H. (2004). Use of ultrasonic energy for intensification of the bio-preparation of greige cotton. Ultrasonics, 42(1-9), 87-91. 